\title{
Impacts of genetic selection on Sequoia sempervirens mini-cutting rooting and initial growth in the field
}

\author{
Queli Cristina Lovatel, Gabriel Teixeira da Rosa, Alexandra Cristina Schatz Sá, \\ Marcio Carlos Navroski* \\ University of the State of Santa Catarina, Lages, Santa Catarina, Brazil \\ Corresponding author: marcio.navroski@udesc.br \\ (Received for publication 26 November 2019; accepted in revised form 24 August 2021)
}

Betel Cavalcante Lopes, Erasmo Luis Tonett, Romell Alves Ribeiro Dias, Mariane de Oliveira Pereira and

\begin{abstract}
Background: Vegetative propagation from superior individuals allows multiple copies of plants that are genetically identical to the parent plant to be obtained. However, vegetative propagation success varies among individual genotypes, with some clones having more difficulty forming roots than others. The aim of this study was to evaluate the genetic gain in Sequoia sempervirens (D.Don) Endl. clones using parameters describing vegetative propagation success and initial growth in field.

Methods: Vegetative propagation success was quantified for 16 clones in a completely randomised design consisting of 10 replications, each containing 10 mini-cuttings. At 90 days, rooting (RT), survival (SV) and the number of new shoots (NS) were evaluated. Performance after planting in the field was assessed using 13 clones from the previous experiment, arranged in linear parcels of 10 plants with 8 replicates. After 18 months, survival (SV), stem diameter (SD), height (H) and dominance breakdown (DB) were assessed. Estimates of variance components, heritability and genetic correlations were obtained using the Selegen-REML/BLUP software.

Results: The mini cuttings of the 16 clones had a coefficient of genetic variation $\left(\mathrm{CV}_{g i} \%\right)$ of $32.32 \%$ for RT, $5.44 \%$ for SV and $5.35 \%$ for NS. The heritability of the total genetic effects $\left(H^{2} g\right)$ for RT was 0.68 . The clones with the best predicted genotypic classifications for the characteristics evaluated in the field were A116, A140 and A138 for SV, A126, A140 and A138 for SD, A138, A140 and A117 for H and A138, A228 and A116 for DB.

Conclusions: In general, it was possible to obtain high genetic gain for rooting and medium gain for dendrometric variables in the field.
\end{abstract}

Keywords: vegetative propagation; clonal test; Selegen-REML/BLUP; selection gain.

\section{Introduction}

The species Sequoia sempervirens (D.Don) Endl. known worldwide as sequoia or redwood, is native to North America, mainly from the central and northern California coast, a region with moderate to high rainfall in winter and fog in summer (Olson et al. 1990; Cown and McKinley 2008). Sequoia wood is widely used for the construction of decks, fences, windows, doors, shutters and interior applications where appearance and stability are important requirements (Cown and McKinley 2008). Sequoia is a species that mainly propagates through seed production, however, the seed germination rate is generally less than $10 \%$ and seedling viability is very low (Ozudogru et al. 2011). In addition, young plants have lower seed viability, with higher values being obtained from 250-year-old trees (Olson et al. 1990). Alternatively, in natural stands the species can reproduce by vegetative propagation. When a tree is cut or burned, sprouts appear from the cut trunk or already established roots and grow more vigorously than other understory plants. Thus, an individual's genetic information is the same as that of the trees that inhabited the site thousands of years ago (Luna 2008). 
For commercial forestry, vegetative propagation from superior individuals allows the multiplication of the best genotypes and plants that are genetically identical to the parent plant to be obtained. It also allows the multiplication of selected trees that contain favourable genetic combinations and the production of genetically homogeneous material that can develop in a predictable and uniform manner (Wendling et al. 2014).

Mini cuttings (cuttings taken from mini hedges not previously rejuvenated by in vitro techniques) is one of the most widely used vegetative propagation techniques. It allows the selection of those individuals with the best characteristics in tree breeding programmes and can reduce the length of the breeding cycle (Freitas et al. 2016). Compared with traditional cutting methods, which suffer from "physiological ageing" problems with the donor plants, mini-cuttings offer advantages in the small size of clonal mini-hedges, high productivity, lower cost and better rooting indices (Majada et al, 2011).

Plant responses to vegetative propagation and their consequences have received little attention in the quantitative genetics literature. By contrast, studies in horticulture and silviculture have examined some aspects of this problem. Genetic variation in rooting ability has been observed in several economically important species and environmental effects on rooting have been widely studied to find methods to optimise rooting of cuttings for commercial production (Schwaegerle 2005). Although rooting is an important factor in the selection of clones in forestry, few studies address the use of this characteristic (rooting) in the early selection of superior genotypes. Our hypothesis is that characteristics such as the rooting of cuttings and initial growth in the field following out-planting can be used as selection criteria for sequoia clones. Therefore, the objective of this work was to evaluate the genetic gain in Sequoia sempervirens clones using parameters related to vegetative propagation success and initial growth in the field.

\section{Methods}

\section{Vegetative propagation and rooting success of mini- cuttings}

The experiment compared the propagation success and rooting of mini-cuttings from sixteen different clones (A100, A113, A115, A116, A117, A126, A127, A130, A131, A133, A135, A136, A138, A140, A227 and A228). Material for the experiment was sourced from stumps of selected 40-year-old sequoia parent trees. Conventional cuttings were collected from the matrix trees 120 days after partial or complete annealing, as described by Pereira et al. (2017). This material was transported to the forest nursery in Lages, Santa Catarina state, Brazil. From this material, $10 \mathrm{~cm}$ cuttings were made, each containing a pair of acicular leaves with the total leaf area reduced by $50 \%$. These cuttings were treated with $6,000 \mathrm{mg} \mathrm{L}^{-1}$ of indole-3-butyric acid (IBA), set in tubes $\left(180 \mathrm{~cm}^{3}\right)$ containing medium-sized $(2-4 \mathrm{~mm})$ vermiculite and commercial substrate $(1: 1 \mathrm{v} / \mathrm{v})$ and placed in a mini-tunnel for rooting to occur.
Five months after these cuttings were set, rooted plants were acclimated in a shade house for 30 days and then transferred to a greenhouse to complete acclimatisation for another 30 days. Subsequently, plants approximately $20 \mathrm{~cm}$ high were transferred to 5 -L pots filled with a commercial substrate consisting of peat and decomposed pine bark (50\%) and medium-sized (2-4 mm) vermiculite (50\%). Fifteen days after installation (the time needed to adapt the plants to the system) the apex of the plant's main sprout was pruned to a height of $10 \mathrm{~cm}( \pm 2 \mathrm{~cm})$, thus forming the ministumps for the establishment of the clonal mini-garden. Pruning of the mini-stumps was performed each month over a four-month period.

The nutrient solution used in the clonal mini-garden was based on commercial fertiliser comprising $10 \%$ $\mathrm{N}$ (water-soluble); $42 \% \mathrm{P}_{2} \mathrm{O}_{5}$ (water soluble); $10 \%$ $\mathrm{K}_{2} \mathrm{O}$ (water soluble); $0.6 \% \mathrm{Mg} ; 0.1 \% \mathrm{Fe}$ and $0.02 \% \mathrm{Br}$. Fertigation was carried out twice a week, with each mini-strain receiving $50 \mathrm{~mL}$ of the solution composed by diluting $1.5 \mathrm{~g}$ of fertiliser in $1 \mathrm{~L}$ of water. After the formation of mini-stumps, shoots were collected for the experiments.

From each clone, 8 to $10 \mathrm{~cm}$ long mini-cuttings were prepared, with the basal portion bevel cut and the upper portion incised transversely, and with a pair of acicular leaves cut in half. Once prepared, the cuttings were placed to root in $180 \mathrm{~cm}^{3}$ polypropylene tubes containing an average size particle (2-4 $\mathrm{mm}$ ) of vermiculite and commercial substrate $(1: 1 \mathrm{v} / \mathrm{v})$ with the addition of $6 \mathrm{~g} \mathrm{~L}^{-1}$ of controlled release fertiliser, in which the insertion of approximately $2 \mathrm{~cm}$ from the base of the mini-cutting into the substrate was made. The commercial plant substrate, according to the manufacturer, is composed of peat, expanded vermiculite, pine bark and charcoal. The chemical and physical characteristics after substrate analysis are as follows: $\mathrm{pH}=6.6$; electrical conductivity $=0.13 \mathrm{mS} \mathrm{cm}^{-1}$; wet density $=450.8 \mathrm{~kg} \mathrm{~m}^{-3}$; dry density $=$ $302.7 \mathrm{~kg} \mathrm{~m}^{-3}$; current humidity $=32.8(\%)$; total porosity $=72.2(\%)$; aeration space = $17.0(\%)$; easily available water $=12.2(\%)$; buffering water $=2.4(\%)$; remaining water $=40.5(\%)$; WHC10 - water holding capacity at $10 \mathrm{~cm}=55.1 ; \mathrm{WHC} 50=42.9$ and WHC100 $=40.5$.

The trays containing the tubes with the minicuttings were placed in a mini-tunnel - plastic covered greenhouse structure (measuring $8.0 \mathrm{~m}$ long $\mathrm{x}$ $1.20 \mathrm{~m}$ wide $\mathrm{x} 0.9 \mathrm{~m}$ high). The temperature inside the greenhouse usually varied between $20-32^{\circ} \mathrm{C}$ and the relative humidity remained above $80 \%$, being irrigated by micro-sprinkling for 5 minutes, five times a day. The mini-cuttings remained in this condition for 90 days, at which time the evaluation of the experiment was performed. The experiment followed a completely randomised design with 10 replications of 10 minicuttings from each clone.

Survival percentage (SV), percentage of rooted cuttings (RT) and the number of new shoots (NS) were evaluated. Mini-cuttings with live wood, old leaves or young shoots, rooted or not, were considered survivors. The rooting percentage was considered over the total, not only the surviving mini-cuttings. The number of 
roots was not evaluated because the plants from the experiment were destined for field planting. Counting the number of roots implies substrate disruption, causing serious damage to the seedling roots.

\section{Initial growth in the field}

The clonal mini-cuttings test was installed in Curitibanos - Santa Cristina (Brazil) in October 2017. The region, according to Koppen, has the mesothermal humid subtropical climate (Cfb) (Alvares et al. 2013). Prior to planting, subsoiling and a rotary hoe were used to prepare the site. Plants from the rooting experiment were used for this study. At the time of planting, they were nine months old. Of the 16 clones used in the rooting experiment, four of them did not have sufficient rooted material for initial growth in the field (A113, A115, A127, A13). Clone A110 was added to field planting experiment but was not used in the rooting experiment.

At the time of planting, the mini-cuttings were approximately $30 \mathrm{~cm}$ tall and had a root-collar diameter greater than $4 \mathrm{~mm}$. Fifteen days before planting, they underwent an acclimatisation period, with reduced irrigation and maintenance in full sun. Fifteen days after planting, $150 \mathrm{~g}$ of NPK (5-20-20) fertiliser was applied to each plant. The growth study was undertaken using 13 clones (A100, A110, A116, A117, A126, A130, A131, A135, A136, A138, A140, A227 and A228) in lines of 10 plants per clone with 8 replicates for a total of 80 plants tested per clone. The planting spacing used was $3.0 \mathrm{x}$ $3.0 \mathrm{~m}$. All clonal stock was in the form of mini-cuttings produced from the clonal mini-garden.

Eighteen months after out-planting in the field, the following variables were measured: survival (SV), stem diameter (SD), height $(\mathrm{H})$ and dominance breakdown (DB) in relation to the early testing of sequoia clones in the field.

\section{Statistical analysis}

Estimates of variance components, heritability and genetic correlations were obtained from mixed models fitted using the Selegen-REML/BLUP software (Resende 2016). An alternative to be used in the construction of indexes that can lead to a more accurate selection process is the use of restricted maximum likelihood (REML) and best linear unbiased prediction (BLUP). This method is based on the assumptions that the smaller the standard deviation of genotypic behaviour between two sites, the greater the harmonic mean of their genotypic values between two sites (Silva et al. 2011; Rosado et al. 2012). The REML/BLUP procedure has several advantages as it considers genotypic effects as random, can deal with imbalance, non-orthogonality and heterogeneity of variances, outliers, correlated errors within locations, provides breeding values after discounting environmental effects, and can be applied to any number of environments (Resende 2007).

Vegetative propagation and rooting success were evaluated assuming a completely randomised design, with testing of unrelated clones and more than one plant per parcel. The following statistical model was used for determining the genetic variance components:

$$
y=X u+Z g+e
$$

where: $\mathrm{y}=$ data vector; $\mathrm{u}=$ fixed effect vector of the general average; $g$ = vector of genotypic effects assumed to be random; $\mathrm{e}=$ error vector or random residue.

The variance components analysed for vegetative propagation and rooting were: $\sigma_{g}^{2}=$ genotypic variance, $\sigma_{e}^{2}=$ residual variance, $\sigma_{f i}=$ individual phenotypic variance, $h_{g}^{2}=$ heritability of individual parcels in the broad sense (i.e., effects of total genotypes), $C V_{g i}(\%)=$ genotypic variation coefficient and $C V_{e}(\%)=$ residual variation coefficient and overall mean of the experiment. Analysis of the different parameters related to the initial growth in the field was undertaken assuming a randomised block experimental design with several plants per parcel and testing of unrelated clones. The following statistical model was used for determining the genetic variance components:

$$
\mathrm{y}=\mathrm{Xr}+\mathrm{Zg}+\mathrm{Wp}+\mathrm{e}
$$

where $\mathrm{y}=$ data vector; $\mathrm{r}=$ repeating effects vector (assumed to be random) plus the overall mean; $\mathrm{g}$ = genotypic effects vector assumed to be random; $\mathrm{p}=$ parceleffectsvector; $\mathrm{e}=$ errorvectororrandom residual. The variance components analysed in the field clone test were: $\sigma_{g}^{2}=$ genotypic variance, $\sigma_{\text {parc }}^{2}=$ environmental variance between parcels, $\sigma_{e}^{2}=$ residual variance, $\sigma_{f i}^{2}=$ individual phenotypic variance, $h_{g}^{2}=$ heritability of individual parcels in the broad sense (i.e., the effects of total genotypes), $h_{a j}^{2}=$ individual heritability in the broad sense (adjusted for parcel purposes), $C_{\text {parc }}^{2}=$ coefficients for determining the effects of parcels, $h^{2}{ }_{m c}=$ heritability of the mean genotype, $A c_{\text {clon }}(\%)=$ the genotype selection accuracy, $C V_{g i}(\%)=$ coefficient of genotypic variation, $C V_{e}(\%)=$ residual coefficient of variation, $C V_{r}=$ coefficient of relative variation, $P E V=$ prediction error variance of the genotypic values, $S E P=$ standard deviation of predicted genotypic value and overall mean of the experiment.

\section{Results}

Vegetative propagation and rooting of mini-cuttings Results from the experiments with sequoia minicuttings showed that there was considerable potential to improve vegetative propagation success through genetic selection. The coefficient of genetic variation $\left(\mathrm{CV}_{g i} \%\right)$ for RT was $32.32 \%$ (Table 1), which was high when compared with the same parameter obtained for SV (5.44) and NS (5.35). Heritability estimates for the SV and NS variables were low, being 0.16 and 0.04 , respectively. With this wide variation, genotypic means for RT ranged from $23.73 \%$ for clone A138 to $98.77 \%$ for clone A113 (Table $2)$. Mean SV values were above $85 \%$ for all clones and NS percentage was above $76 \%$. The best results for RT were obtained for clones A113 (97.7\%), A127 (97.8\%), A136 (96.9\%) and A115 (94.5\%). These same clones exhibited good performance across the other traits that were assessed.

The heritability of the total genetic effects $\left(h^{2}\right)$ for the rooting variable was considered high $(0.68)$, which has 
TABLE 1: Variance components for the survival (SV), rooting (RT) and number of new shoots (NS) for 16 Sequoia sempervirens clones measured 90 days after setting.

\begin{tabular}{lccc}
\hline Component & SV (\%) & RT (\%) & NS \\
\hline$\sigma_{g a}^{2}$ & 26.70 & 580.00 & 19.45 \\
$\sigma^{2}{ }_{e}$ & 131.31 & 262.49 & 401.17 \\
$\sigma^{2}{ }_{f i}$ & 158.02 & 842.50 & 420.62 \\
$h^{2}{ }_{a}$ & $0.1689 \pm(0.0841)$ & $0.6884 \pm(0.1698)$ & $0.0462 \pm(0.044)$ \\
$C V_{g i}(\%)$ & 5.44 & 32.32 & 5.35 \\
$C V_{e}(\%)$ & 12.06 & 21.74 & 24.30 \\
General average & 94.98 & 74.49 & 82.41 \\
\hline
\end{tabular}

important implications for the genetic selection of clones as this is the most limiting feature for the propagation of clones via mini-cuttings.

\section{Initial growth in the field}

The clones with the highest survival when planted in the field were A116, A140 and A138; for stem diameter the best performing clones were A126, A140 and A138; for height: the best performing clones were A138, A140 and A117 and for dominance breakdown the best performing clones were A138, A228 and A116 (Table 3). One of the best performing clones in the field (A138) had the worst rooting score in the greenhouse experiment, and by contrast clone A136, which showed poorer field performance, had the third best rooting score (Table 2). Genotypic mean values $(u+g)$ ranged from 0.33 to 0.81 (\%) for SV; 12.02 to 27.25 (mm) for SD; 58.60 to $118.53(\mathrm{~cm})$ for $\mathrm{H}$ and 0.42 to $0.70(\%)$ for DB. The worst performing clones in terms of survival, stem diameter, height and dominance breakdown were A117, A228, A228 and A136, respectively. High values of genotypic coefficients of variation (20.06 to $34.48 \%$ ) were found, indicating that these traits, especially survival, have good potential to be selected for (Table 4). The heritability of

TABLE 2: Genotype classification by predicted genotypic effect $(g)$ and genotypic mean $(u+g)$ for rooting (RT), survival (SV) and number of new shoots (NS) of Sequoia sempervirens clones evaluated at 90 days after setting.

\begin{tabular}{|c|c|c|c|c|c|c|c|c|c|}
\hline \multirow{2}{*}{ Clone } & \multicolumn{3}{|c|}{ RT (\%) } & \multicolumn{3}{|c|}{ SV (\%) } & \multicolumn{3}{|c|}{ NS } \\
\hline & $\mathbf{R K}^{\mathbf{1}}$ & $g$ & $u+g$ & RK & $g$ & $u+g$ & RK & $g$ & $u+g$ \\
\hline A100 & 15 & -35.8052 & 38.6894 & 4 & 3.2440 & 98.2274 & 11 & -0.902 & 81.5105 \\
\hline A113 & 1 & 24.2842 & 98.7788 & 7 & 2.0225 & 97.0060 & 7 & 0.786 & 83.1988 \\
\hline A115 & 4 & 20.0443 & 94.5389 & 6 & 2.3987 & 97.3822 & 13 & -1.314 & 81.0987 \\
\hline A116 & 8 & 9.4153 & 83.9099 & 11 & 1.0166 & 96.0000 & 10 & -0.687 & 81.7257 \\
\hline A117 & 13 & -25.0068 & 49.4878 & 13 & -4.7069 & 90.2765 & 3 & 2.621 & 85.0745 \\
\hline A126 & 14 & -33.6137 & 40.8809 & 16 & -9.7276 & 85.2559 & 14 & -2.504 & 79.9084 \\
\hline A127 & 2 & 23.3836 & 97.8782 & 5 & 2.6909 & 97.6744 & 2 & 3.671 & 86.1796 \\
\hline A130 & 11 & 2.8962 & 77.3908 & 9 & 1.5486 & 96.5320 & 15 & -3.831 & 78.5816 \\
\hline A131 & 12 & -6.8018 & 67.6928 & 8 & 1.9007 & 96.8842 & 12 & -0.942 & 81.4709 \\
\hline A133 & 9 & 9.3564 & 83.8510 & 1 & 3.7779 & 98.7614 & 1 & 4.094 & 86.5065 \\
\hline A135 & 10 & 4.8486 & 79.3433 & 12 & 0.1708 & 95.1543 & 9 & -0.196 & 82.2168 \\
\hline A136 & 3 & 22.4858 & 96.9804 & 3 & 3.2440 & 98.2274 & 4 & 1.732 & 84.1442 \\
\hline A138 & 16 & -50.7630 & 23.7316 & 2 & 3.7779 & 98.7614 & 16 & -5.761 & 76.6514 \\
\hline A140 & 7 & 11.1684 & 85.6630 & 14 & -6.4140 & 88.5695 & 5 & 1.707 & 84.1199 \\
\hline A227 & 5 & 12.5510 & 87.0457 & 10 & 1.5201 & 96.5035 & 8 & 0.185 & 82.5976 \\
\hline A228 & 6 & 11.5567 & 86.0513 & 15 & -6.4642 & 88.5193 & 6 & 1.202 & 83.6145 \\
\hline
\end{tabular}

\footnotetext{
${ }^{1}$ Genotype ranking
} 
TABLE 3: Genotype classification by predicted genotypic effect $(g)$ and genotypic mean $(u+g)$ for the survival (SV), stem diameter (SD), height (H) and dominance break (DB) for Sequoia sempervirens clones evaluated at 18 months after out-planting in the field.

\begin{tabular}{|c|c|c|c|c|c|c|c|c|c|c|c|c|}
\hline \multirow{2}{*}{ Clone } & \multicolumn{3}{|c|}{ SV (\%) } & \multicolumn{3}{|c|}{ SD (mm) } & \multicolumn{3}{|c|}{$H(\mathrm{~cm})$} & \multicolumn{3}{|c|}{ DB } \\
\hline & $\mathbf{R K}^{\mathbf{1}}$ & $g$ & $u+g$ & RK & $g$ & $u+g$ & RK & $g$ & $u+g$ & RK & $g$ & $u+g$ \\
\hline A100 & 4 & 0.1446 & 0.6680 & 9 & -1.3003 & 19.8897 & 7 & -0.4797 & 88.3223 & 7 & 0.0569 & 0.6393 \\
\hline A110 & 10 & -0.1230 & 0.4005 & 12 & -1.8618 & 19.3283 & 8 & -4.1648 & 84.6372 & 4 & 0.1026 & 0.6850 \\
\hline A116 & 1 & 0.2866 & 0.8100 & 5 & 0.8082 & 21.9982 & 4 & 6.7229 & 95.5248 & 3 & 0.1031 & 0.6855 \\
\hline A117 & 13 & -0.1947 & 0.3288 & 8 & -0.7677 & 20.4224 & 3 & 7.5452 & 96.3472 & 6 & 0.0619 & 0.6443 \\
\hline A126 & 5 & 0.0568 & 0.5802 & 1 & 6.0628 & 27.2528 & 5 & 2.4033 & 91.2052 & 12 & -0.1270 & 0.4554 \\
\hline A130 & 12 & -0.1738 & 0.3496 & 7 & -0.6574 & 20.5327 & 10 & -5.3187 & 83.4832 & 10 & -0.1183 & 0.4641 \\
\hline A131 & 11 & -0.1428 & 0.3807 & 10 & -1.5317 & 19.6584 & 6 & 1.1233 & 89.9253 & 8 & 0.0070 & 0.5894 \\
\hline A135 & 8 & -0.0845 & 0.4389 & 4 & 1.9368 & 23.1268 & 9 & -4.2276 & 84.5743 & 5 & 0.0792 & 0.6616 \\
\hline A136 & 9 & -0.1031 & 0.4203 & 11 & -1.5331 & 19.6570 & 12 & -10.0620 & 78.7400 & 13 & -0.1601 & 0.4223 \\
\hline A138 & 3 & 0.1700 & 0.6934 & 3 & 3.8569 & 25.0469 & 1 & 29.7256 & 118.5276 & 1 & 0.1226 & 0.7050 \\
\hline A140 & 2 & 0.1802 & 0.7037 & 2 & 4.4807 & 25.6707 & 2 & 14.7124 & 103.5143 & 9 & -0.1142 & 0.4681 \\
\hline A227 & 7 & -0.0485 & 0.4749 & 6 & -0.3222 & 20.8678 & 11 & -7.7769 & 81.0251 & 11 & -0.1226 & 0.4597 \\
\hline A228 & 6 & 0.0325 & 0.5560 & 13 & -9.1713 & 12.0187 & 13 & -30.2030 & 58.5989 & 2 & 0.1089 & 0.6913 \\
\hline
\end{tabular}

${ }^{1} \mathrm{RK}$ - Genotype ranking

parcels in relation to genotypes (0.093 to 0.157$)$ was not as high as that for rooting (0.688), but values for the SD and $\mathrm{H}$ traits were close to those found for quantitative selection traits in other species $(0.157$ and 0.148 respectively). Individual heritability values for parcel effects were very similar compared to the effects of total genotypes ( 0.103 to 0.157 ).

\section{Discussion}

The coefficients of genetic variation, both at an individual level $\left(C v_{g i}\right)$ and progeny level $\left(C v_{g p}\right)$ are accepted as essential indicators of existing variation, allowing the estimation of genetic gains in provenance and progeny tests (Sebbenn et al. 2009; Rosado et al. 2012). The genotypic coefficient of variation values estimated for

TABLE 4: Variance components for survival (SV), stem diameter (SD), height (H) and dominance breakdown (DB) of Sequoia sempervirens clones evaluated at 18 months after out-planting in the field.

\begin{tabular}{lcccc}
\hline Component & SV (\%) & SD ( mm) & H (cm) & DB \\
\hline$\sigma_{g}^{2}$ & 0.03 & 22.83 & 317.30 & 0.02 \\
$\sigma^{2}{ }_{\text {parc }}$ & 0.00 & 0.23 & 92.15 & 0.03 \\
$\sigma^{2}{ }_{e}$ & 0.21 & 122.13 & 1722.83 & 0.20 \\
$\sigma_{f i}^{2}$ & 0.25 & 145.20 & 2132.28 & 0.25 \\
$h_{g}^{2}$ & $0.1320 \pm 0.0557$ & $0.1572 \pm 0.0799$ & $0.1488 \pm 0.0777$ & $0.0929 \pm 0.0614$ \\
$h^{2}{ }_{a j}$ & 0.1321 & 0.1575 & 0.1555 & 0.1033 \\
$C^{2}{ }_{\text {parc }}$ & 0.00 & 0.00 & 0.04 & 0.10 \\
$h^{2}{ }_{m c}$ & 0.6628 & 0.7035 & 0.5854 & 0.3645 \\
$A c_{\text {clon }}(\%)$ & 0.81 & 0.84 & 0.77 & 0.60 \\
$C V_{g i}(\%)$ & 34.48 & 22.55 & 20.06 & 26.19 \\
$C V_{e}(\%)$ & 24.59 & 14.64 & 16.88 & 34.58 \\
$C V_{r}(\%)$ & 1.40 & 1.54 & 1.19 & 0.76 \\
$P E V(\%)$ & 0.01 & 6.77 & 131.54 & 0.01 \\
$S E P(\%)$ & 0.10 & 2.60 & 11.47 & 0.12 \\
General average & 0.52 & 21.19 & 88.80 & 0.58 \\
\hline
\end{tabular}


the RT trait in mini-cuttings and for SV, SD, $\mathrm{H}$ and DB traits in field trials were all above $20 \%$. Coefficients of genetic variation $\left(\mathrm{Cv}_{\mathrm{g}}\right)$ above $10 \%$, as found in the present study, indicate that there is considerable genetic variability to be explored and that there are genetically superior clones in the experiment (Villacorta et al. 2015; Stovall et al. 2011). This value demonstrates elevated experimental precision, meaning that the model was able to capture most of the variation in the test and, as such, the estimates can be trusted. These values are similar to those found by Westbrook et al. (2015) and Sykes et al. (2006) for loblolly pine (Pinus taeda).

Based on Resende (2007), the accuracy observed was high for survival (SV), stem diameter (SD) and height $(\mathrm{H})$, and was similar to the accuracy levels reported in other studies on forestry species (Gapare et al. 2015). The observed value of $\mathrm{Ac}_{\text {clon }}$ indicates that selection based on SV, SD and $\mathrm{H}$ can be considered accurate, as the true values (which are unknown) and predicted values are very similar.

Estimates of genetic parameters are important for directing breeding programmes, as they aid the selection process and serve as a theoretical framework to support the recommendations of commercial materials (Maia et al. 2009). However, it should be noted that this variation cannot be related only to the effects of heritability in the broad sense, i.e., the proportion of variability caused by the effects of genes (Jung et al. 2008). This variation may also be linked to the clonal C-effects (Pereira et al. 2018). C-effects can result in an artificial increase in clonal variation, which may increase the estimates of genetic gains in clonal selection (Frampton \& Foster 1993). According to the same authors, this discrepancy may be due to the problems associated with vegetative propagation and the degree of environmental variation in the place where the clonal test is performed.

Overall, the best rooting clones were the ones with the poorest field performances, as was the case with clones A138 and A140, which had good rankings for the field variables, while in rooting their positions were intermediate to poor (16 and 7 respectively). By contrast, clone A136 which ranked third best for the RT trait demonstrated poorer field results for all four characteristics evaluated. Differences in rooting may be associated with differences in subsequent growth. These differences may be related to carryover effects, or C-effects, which are intergenerational environmental effects that occur when the performance of vegetative propagules is influenced by the environment in which the propagules developed. C-effects can also bias estimates of genetic and environmental parameters in plant growth studies by inflating variation among genotypes. C-effects arise from environmental differences among plants used as the source for cuttings: plants of the previous clonal generation (Schwaegerle 2005).

Although good levels of rooting were generally achieved, plants produced by sequoia mini-cuttings can be inefficient in the acclimatisation process and this can lead to high mortality, which requires careful consideration of environmental variables, particularly high temperatures (Luna 2008). Clones A113, A115 and
A127, which were in the top four in the percentage of RT, were not field tested due to high levels of nursery mortality and the resulting lack of material for planting.

The heritability of individual parcels of total genotypic effects found for rooting was high (0.68); values above 0.5 are considered high (Resende 2002), indicating the possibility for satisfactory gains with selection for this propagation trait for sequoia mini-cuttings. However, vegetative propagation traits, such as rooting, must have a secondary and auxiliary character, the most important parameters for selection being those related to the survival, shape and productivity of trees in the field.

For field evaluations, heritability was only found to be close to the normal range for quantitative traits (0.15- 0.5$)$ for SD and H. Polygenic traits such as diameter and height have complex gene interactions. They are highly influenced by the environment, making it difficult to identify superior genotypes based on the phenotype (Chinelato et al. 2014). Heritability cannot be fully assumed as part of the additive genetic variance, which is relative to the variance due to the additive effects of the genes and should only serve as an indication of the possibility of gain for future generations. One of the most important functions of this parameter in genetic breeding studies is its predictive role. Heritability is the main indicator of success in the selection process, with higher values indicating greater genetic gains (Braga et al. 2020).

One of the reasons that the heritability values for SD (0.158) and $H(0.149)$ are not higher in the present study may be due to the early evaluation period, since these traits have greater variation over time. Variation in plant size can arise from genetic and environmental responses to vegetative propagation, in addition to variation caused by direct genetic and environmental effects on plant growth (Schwaegerle 2005).

The low heritability for DB (0.09) was undesirable, as this characteristic is fundamental for stem quality, which is directly related to the final value of the product. Therefore, the presence of apical dominance may be a limiting factor in the selection. In another field planting study reported by Pereira (2018), sequoia plants lost their apical dominance due to attack by a grasshopper (Chromacris speciosa), something that may have happened in this field test, where the presence of the insect was observed.

Although it did not cause high mortality in the current study, the occurrence of frost may cause the breakdown of apical dominance. Very intense frosts can cause mortality, as observed in the study by Pereira (2018). Frosts were also responsible for the loss of trees planted in colder areas of New Zealand (Dean 2007). For each plant species there is a temperature at which protoplasm freezing will occur and may occur before the air temperature reaches $0^{\circ} \mathrm{C}$. Some species may have a higher resistance to freezing, remaining alive even after the phenomenon has occurred, but mortality may occur in younger tissues, such as the apex (Perissato et al. 2013). Kreyling et al. (2015) observed a cold tolerance of up to $-9.2^{\circ} \mathrm{C}$ for Sequoia sempervirens. In the same study, the authors also observed that the thermal amplitude 
was one of the main factors responsible for high levels of damage to the plants.

Overall, considering genetic heritability, RT selection is easier. In addition to being a qualitative trait (influenced by fewer genes than quantitative traits), which generally has a higher heritability, it is an important variable determining the success of vegetative propagation of plants on a large scale for supplying commercial plantations. Among the various genetic parameters estimated in progeny tests, one of the most important is the heritability coefficient, which measures the genetic control existing in a trait, and therefore the breeder's potential to improve a trait through genetic selection. However, the phenotypic characteristics observed in the field, such as stem shape, growth and adaptation are the most important for the selection of superior genetic materials.

Therefore, consideration should be given to the development of clones in the field over time, in accordance with the desirable characteristics of the final product (e.g., volume, height, diameter, density, etc.) and thus to define other selection parameters. In general, the results from this study allow for different scenarios for the selection of genetic material (clones). Good results for selection were obtained for rooting, but as already stated, this trait must be complementary to phenotypic traits in the field which are the most important for selection, particularly for species grown in commercial plantations in Brazil. However, further studies and new introductions of genetic materials should be carried out, given that the origin of the seminal material that generated the rescued and propagated sequoia mother trees is unknown. There may be genetic proximity between the clones used in this study if the seeds were collected at the same site.

\section{Conclusions}

Genetic selection for rooting success in sequoia clones proved to be effective, with this trait showing a high heritability. All traits evaluated in field yielded satisfactory results for selection, indicating that there is potential for genetic gain through clonal selection.

\section{Authors' contributions}

QCL and GTR evaluated the experiment, conducted statistical and genetic analysis, wrote the manuscript, and provided critical revisions of the manuscript. ACSS, BCL, ELT and RARD evaluated the experiment and provided critical revisions of the manuscript. MOP and MCN designed the experiment and supervised the entire research. All authors read and approved the final manuscript.

\section{References}

Alvares, C.A., Stape, J.L., Sentelhas, P.C., Goncalves, J.L.M. \& Sparovek, G. (2013). Köppen's climate classification map for Brazil. Meteorologische Zeitschrift, 22(6): 711728. https://doi.org/10.1127/09412948/2013/0507
Braga, R.C., Paludeto, J.G.Z., Souza, B.M., Aguiar, A.V., Pollnow, M.F.M., Carvalho, A.G.M. \& Tambarussi, E.V. (2020). Genetic parameters and genotype $\times$ environment interaction in Pinus taeda clonal tests. Forest Ecology and Management, 474: 118342. https://doi.org/10.1016/i.foreco.2020.118342

Chinelato, F.C.S., Moraes, C.B., Carignato, A., Tambarussi, E.V., Zimback, L., Palomino, E.C. \& Mori, E.S. (2014). Genetic variability in guapuruvu Schizolobium parahyba progênies. Scientia Agropecuaria, 5(2), 71-76. https://doi.org/10.17268/sci. agropecu.2014.02.01

Cown, D. \& Mckinley, R.B. (2009). Wood properties of 38-year-old redwood from Mangatu forest. New Zealand Journal of Forestry, 54(2), 25-32.

Dean, M. (2007). Coast redwood silviculture in New Zealand. New Zealand Tree Grower, 1, 6-7.

Frampton, L.J. \& Foster, G.S. Field testing vegetative propagules. In: Ahuja, M.R. \& Libby, W.J. (Ed.). Clonal forestry: genetics and biotechnology. Budapest: Springer-Verlag, 1993. p. 110-134. https://doi. org/10.1007/978-3-642-84175-0_9

Freitas, T. P., Barroso, D.G., Lamônica, K. R. \& Carvalho, G.C.M.W. (2016). Aplicação de AIB e tipo de miniestacas naprodução demudas de Handroanthus heptaphyllus Mattos. Ciência Florestal, 26(1), 313320. https://doi.org/10.5902/1980509821128

Gapare, W.J., Ivković, M., Liepe, K.J., Hamann, A. \& Low, C.B. (2015). Drivers of genotype by environment interaction in radiata pine as indicated by multivariate regression trees. Forest Ecology and Management, 353(1), 21-29. https://doi. org/10.1016/j.foreco.2015.05.027

Jung, M. S., Vieira, E. A., Brancker, A. \& Nodari, R. O. (2008). Herdabilidade e ganho genético em caracteres do fruto do maracujazeiro-doce. Revista Brasileira de Fruticultura, 30(1), 209-214. https:// doi.org/10.1590/S0100-29452008000100038

Kreyling, J., Schmid, S. \& Aas, G. (2015). Cold tolerance of tree species is related to the climate of their native ranges. Journal of Biogeography, 42(1), 156-166. https://doi.org/10.1111/jbi.12411

Luna, T. (2008). Vegetative Propagation of Coastal Redwood (Sequoia sempervirens (Lamb. ex D. Don) Endl.). Native Plants Journal, 9(1), 25-28. https:// doi.org/10.2979/NPJ.2008.9.1.25

Majada, J., Martínez-Alonso, C., Feito, I., Kidelman, A., Aranda, I., \& Alía, R. (2011). Mini-cuttings: an effective technique for the propagation of Pinus pinaster Ait. New Forests, 41(3), 399-412. https:// doi.org/10.1007/s11056-010-9232-X

Maia, M.C.C., Resende, M.D.V., Paiva, J.R., Cavalcanti, J.J.V. \& Barros, L. M.B. (2009). Seleção simultânea para produção, adaptabilidade e estabilidade genotípicas em clones de cajueiro, via modelos 
mistos. Pesquisa Agropecuária Tropical, 39(1), 43-50.

Olson, D.F., Roy, D.F. \& Walters, G.A. (1990). Sequoia sempervirens (D. Don) Endl. Redwood. In: Burns, R.M and Honkala, B,H. (technical coordinators) Silvics of North America. Agriculture Handbook 654. Washington DC, USA: US Department of Agriculture, Forest Service, pp. 541-551.

Ozudogru, E.A., Kirdok, E., Kaya, E., Capuana, M., Benelli, C. \& Engelmann, F. (2011). Cryopreservation of Redwood (Sequoia sempervirens (D. Don.) Endl.) in vitro buds using vitrification-based techniques. CryoLetters, 32(2), 99-110.

Pereira, M.O, Ângelo, A.C., Navroski, M.C., Dobner Júnior, M. \& Oliveira, L.M. (2017). Vegetative rescue and rooting of cuttings of different stock plants of Sequoia sempervirens. Cerne, 23(4), 435-444. https://doi.org/10.1590/010477602017230424 $\underline{52}$

Pereira, M.O. (2018). Resgate, propagação vegetativa $e$ crescimento inicial DE Sequoia sempervirens (D. Don.) Endl., 225 p. Tese de doutorado da Universidade Federal do Paraná, Curitiba.

Pereira, M.O., Ângelo, A.C., Navroski, M.C., Nicoletti, M.F., Nascimento, B., Sá, A.C.S., Gasparin, E. \& Lovatel, Q.C. (2018). Roots of mini-cutting of clones of Sequoia sempervirens in different seasons of the year. Cerne, 24(4), 452-460. https://doi.org/10.15 90/01047760201824042604

Perissato, S. M., Marcelino, W.L., Acco, L.F., Cabral, A.C., Pinto, L.P. \& Frigo, J.P. (2013). Efeito das geadas em culturas energéticas. Revista Brasileira de Energias Renováveis, 2(4), 49-58. https://doi.org/10.5380/ rber.v2i4.35793

Resende, M.D.V. (2002). Software SELEGEN-REML/BLUP. Colombo: Embrapa Florestas. 67 p. (Embrapa Florestas, Documento, 77).

Resende, M.D.V. (2007). SELEGEN-REML/BLUP: sistema estatístico e seleção genética computadorizada via modelos lineares mistos. Colombo: Embrapa Florestas.

Resende, M.D.V. (2016). Software Selegen-REML/BLUP: a useful tool for plant breeding. Crop Breeding and Applied Biotechnology, 16(4), 330-339. https:// doi.org/10.1590/1984-70332016v16n4a49

Rosado, A.M., Rosado, T.B., Alves, A.A., Laviola, B.G.E. \& Bhering, L.L. (2012). Seleção simultânea de clones de eucalipto de acordo com produtividade, estabilidade e adaptabilidade. Pesquisa Agropecuária Brasileira, 47(7), 964-971. https:// doi.org/10.1590/S0100-204X2012000700013

Schwaegerle, K.E. (2005). Quantitative genetic analysis of plant growth: biases arising from vegetative propagation. Evolution, 59(6), 1259-1267. https:// doi.org/10.1111/j.0014-3820.2005.tb01776.x
Sebbenn, A.M., Freitas, M.L.M., Zanatto, A.C.S. \& Morais, E. (2009). Comportamento da variação genética entre e dentro de procedências e progênies de Gallesia integrifolia Vell. Moq. para caracteres quantitativos. Revista do Instituto Florestal, 21(2), 151-163.

Silva, G.O., Carvalho, A.D.F., Veira, J.V. \& Benin, G. (2011). Verificação da adaptabilidade e estabilidade de populações de cenoura pelos métodos AMMI, GGE biplot e REML/BLUP. Bragantia, 70(3), 494-501. $\quad$ https://doi.org/10.1590/S0006$\underline{87052011005000003}$

Stovall, J.P., Carlson, C.A., Seiler, J.R., Fox, T.R. \& Yanez, M.A. (2011). Growth and stem quality responses to fertilizer application by 21 loblolly pine clones in the Virginia Piedmont. Forest Ecology and Management, 261(3), 362-372. https://doi. org/10.1016/j.foreco.2010.10.018

Sykes, R., Li, B., Isik, F., Kadla, J. \& Chang, H.M. (2006). Genetic variation and genotype by environment interactions of juvenile wood chemical properties in Pinus taeda L. Annals of Forest Science, 68(3), 897-904. https://doi.org/10.1051/ forest: 2006073

Villacorta, A.M.G., Martin, T.A., Jokela, E.J., Cropper Jr, W.P., Gezan, S.A. (2015). Variation in biomass distribution and nutrient content in loblolly pine (Pinus taeda L.) clones having contrasting crown architecture and growth efficiency. Forest Ecology and Management, 342(1), 84-92. https://doi. org/10.1016/j.foreco.2015.01.012

Wendling, I., Trueman, S. J. \& Xavier, A. (2014). Maturation and related aspects in clonal forestrypart II: reinvigoration, revitalization and juvenility maintenance. New Forests, 45(1), 473-486. https://doi.org/10.1007/s11056-014-9415-y

Westbrook, J.W., Walker, A.R., Neves, L.G., Munoz, P., Resende Jr, M.F., Neale, D.B. \& Peter, G.F. (2015). Discovering candidate genes that regulate resin canal number in Pinus taeda stems by integrating genetic analysis across environments, ages, and populations. New Phytologist, 205(2), 627-641. https://doi.org/10.1111/nph.13074 